\title{
DOSES OF VINASSE AND ITS EFFECTS AT THE PHYSICAL ATTRIBUTES OF RHODIC HAPLUDOX UNDER SUGAR CANE
}

Eber Augusto Ferreira do Prado ${ }^{1}$, Antonio Carlos Tadeu Vitorino ${ }^{1}$, Bruno Agostini Colman ${ }^{1}$, Simone Candido Ensinas ${ }^{1} \&$ Jorge Wilson Cortez ${ }^{1}$

${ }^{1}$ Universidade Federal da Grande Dourados - UFGD. E-mail: eberprado@ hotmail.com, antoniovitorino@ufgd.edu.br, agostinicolman@hotmail.com, simone_candido@hotmail.com, jorgecortez@ufgd.edu.br

\section{ABSTRACT}

The incorporation of vinasse (sugarcane manure) is a common practice in the management of sugarcane cultivation. The aim of this work was to evaluate the physical attributes of the soil in the area planted with sugarcane after application of vinasse. The trial was based on a randomized block design in a split-split-plot scheme $(4 \times 4 \times 3)$, four vinasse doses $\left(0,450,600\right.$ and $\left.750 \mathrm{~m} 3 \mathrm{ha}^{-1}\right)$, four depths $(0,0-0,5$; $0,5-0,10 ; 0,10-0,20$; and 0,20-0,40 m) and three harvest of evaluation (38, 75 and 111 days) after application of the vinasse, with five replicants. Soil bulk density (SD), macroporosity (macro), total porosity (TP), geometric mean diameter (GMD), weighted mean diameter (MWD), and organic matter $(\mathrm{OM})$ were determined as variables studies of this research from samples taken of undesturbed soil. The increase of vinasse doses decreased the soil bulk density, but an increase of the Macro, TP, GMD, MWD, and OM, demonstrating improvement of soil physical attributes.

Keywords: Aggregation, soil bulk density, soil physical quality

\section{DOSES DE VINHAÇA E SEUS EFEITOS NOS ATRIBUTOS FÍSICOS DE LATOSSOLO SOB CANA DE AÇÚCAR}

\section{RESUMO}

A aplicação de vinhaça é prática comum no manejo da cultura da cana-de-açúcar. Assim, objetivou-se com o presente trabalho, avaliar os atributos físicos do solo em área cultivada com cana-deaçúcar após aplicação de doses de vinhaça. Seguiu-se o delineamento experimental de blocos casualizados em esquema de parcelas sub-subdividida $(4 \times 4 \times 3)$, sendo avaliadas quatro doses de vinhaça 
$\left(0 ; 450 ; 600\right.$ e $\left.750 \mathrm{~m}^{3} \mathrm{ha}^{-1}\right)$, quatro profundidades $(0,0-0,5 ; 0,5-0,10 ; 0,10-0,20$ e $0,20-0,40 \mathrm{~m})$, e três ocasiões de avaliação (38, 75 e 111 dias) após aplicação da vinhaça, com cinco repetições. Foram retiradas amostras indeformadas e determinados: densidade do solo (DS), macroporosidade (Macro), porosidade total (PT), diâmetro médio geométrico (DMG), diâmetro médio ponderado (DMP) e teor de matéria orgânica (MO). O aumento das doses de vinhaça diminuiu a densidade do solo, aumentou a Macro, PT, DMG, DMP e MO, demonstrando melhoria dos atributos físicos do solo.

Palavras-chave: Agregação, densidade do solo, qualidade física do solo

\section{INTRODUCTION}

Vinasse is one of the main residues generated from the process of manufacturing fuel alcohol from sugarcane. During the production process of alcohol, an average of 13 liters of vinasse is generated for each liter of ethanol, and almost all of this vinasse is applied to the soil as ferti-irrigation throughout the growing season of the sugarcane farming (OLIVEIRA et al., 2013).

In another context, the use of vinasse has been discussed not only as a biofertilizer, but also as a soil conditioner, promoting the improvement of its physical quality. In the areas cultivated with sugarcane, soil management with heavy machinery has been increasingly used in the sugar cane producing farms, which has often provided a reduction in the structural quality of the soils due to the compaction caused by the intensive machinery traffic, mainly in the inadequate humidity (PEREIRA et al., 2015).

In order to overcome this problem, vinasse application has been presented as an alternative, since it contains a large amount of organic matter, which after its decomposition improves soil physical structure quality (MATOS et al., 2013).

The organic compounds with high molecular weight have large amount of organic radicals, which interact differently with the mineral surface, resulting in electrostatic forces, cation bonds, hydrogen bonds, and van der Waals forces (BAYER \& MIELNICZUK, 2008 and MEURER, 2010). However, low molecular weight organic acids from microbial metabolism and root decomposition, plant residues and root exudation are important in the stabilization of soil aggregates (microaggregates) (GARCIA \& ROSOLEM, 2010). On the other hand, the stability of the macroaggregates, formed from the linkages of microaggregates, has as important organic agents in the aggregation to fungi hyphae and a fraction of the 
organic matter with a small degree of decomposition called light organic matter or particulate organic matter (GARCIA \& ROSOLEM, 2010).

The organic matter added to the soil is responsible for the combination of primary, micro and macroaggregated particles in larger structural units, which compose the process of soil aggregation (RIBEIRO et al., 2013).

Prado et al. (2014), working with clayey dystroferric Red Latosol under application of vinasse doses, observed reduction of the dispersion index particles and consequently greater stability of the aggregates. This reflects, above all, the highest levels of total organic carbon and particulate organic matter resulting from the applied soil management.

It is worth noting that soil aggregation interferes with soil physical quality, since it controls internal water, air, heat, and root growth (VASCONCELOS et al., 2010). Therefore, the higher the organic matter content in the soil, the lower the density and the higher the amount of macropores and total porosity (JIANG et al., 2012).

Therefore, the increase of the organic matter concentration promoted by the addition of vinasse doses is beneficial, both for the improvement of soil fertility by increasing the cation exchange capacity and stabilizing action in the aggregates. From these effects, indirectly, other physical attributes such as soil bulk density, macroporosity, total porosity and pore size, penetration resistance, and average aggregate diameter are affected.

For this context, this work aimed at evaluating the effect of the application of vinasse doses on the physical attributes of the soil in an area cultivated with sugarcane.

\section{MATERIAL AND METHODS}

This study was carried out in the commercial area of the Monte Verde Plant (Bunge - SA), in the municipality of Ponta Porã, Mato Grosso do Sul, Brazil, during the years 2010 and 2011, located at latitude $22^{\circ} 16^{\prime} \mathrm{S}$ and longitude $55^{\circ} 07^{\prime} \mathrm{W}$, with $400 \mathrm{~m}$. The climate of the region is classified as CWA, characterized humid mesothermic climate, with average precipitation of $1200 \mathrm{~mm}$ per year, with the average annual temperature of $22^{\circ} \mathrm{C}$.

The soil in the experimental area was classified as a clayey Rhodic Hapludox, according to the soil taxonomy system (Soil Survey Staff, 2014), and as a Latossolo Vermelho Distrófico típico (LVd), according to the Brazilian soil classification system (Santos et al., 2013). 


\section{DOSES OF VINASSE AND ITS EFFECTS AT THE PHYSICAL ATTRIBUTES OF RHODIC HAPLUDOX}

UNDER SUGAR CANE

The deformed soil samples in the $0.00-0.20 \mathrm{~m}$ layer were collected for soil chemical characterization (Table 1), according to the methodology described by Silva (2009).

Table 1. Soil chemical analysis from the experimental area.

\begin{tabular}{lllllllllll}
\hline $\begin{array}{l}\text { Layer } \\
\text { M }\end{array}$ & $\begin{array}{l}\mathrm{pH} \\
\mathrm{Cacl}_{2}\end{array}$ & $\begin{array}{l}\mathrm{M} . \mathrm{O} \\
\mathrm{g} \mathrm{Kg}^{-1}\end{array}$ & $\begin{array}{l}\mathrm{P} \\
\mathrm{mg} \mathrm{dm}^{-1}\end{array}$ & $\mathrm{H}+\mathrm{Al}$ & $\mathrm{K}$ & $\begin{array}{c}\mathrm{Ca} \\
\mathrm{Cmol}_{\mathrm{c}} \mathrm{dm}^{-3}\end{array}$ & $\mathrm{CTC}$ & $\mathrm{SB}$ & $\begin{array}{l}\mathrm{V} \\
\%\end{array}$ \\
\hline $0,00-0,20$ & 4,5 & 6,0 & 4,23 & 2,66 & 0,08 & 2,8 & 0,52 & 6,1 & 3,45 & 56,5 \\
\hline $0,20-0,40$ & 4,0 & 5,0 & 3,5 & 3,0 & 0,04 & 1,7 & 0,18 & 4,92 & 1,92 & 39,02 \\
\hline \multicolumn{8}{c}{ After application of vinasse doses } \\
\hline $0,00-0,20$ & 5,7 & 8,1 & 34,0 & 1,2 & 0,22 & 5,0 & 1,3 & 7,7 & 6,5 & 84,40 \\
\hline $0,20-0,40$ & 5,0 & 5,6 & 21,0 & 2,73 & 0,13 & 2,17 & 0,42 & 5,45 & 2,72 & 49,90 \\
\hline
\end{tabular}

The tials were carried out in a randomized block design with five replicants, four vinasse doses $\left(0,450,600\right.$ and $\left.750 \mathrm{~m} 3 \mathrm{ha}^{-1}\right)$, four depths $(0,0-0,5 ; 0,5-0,10 ; 0,10-0,20$ e 0,20-0,40 m) and three harvest times, at 38, 75 and 111 days after application of the vinasse doses, in plots of $24 \mathrm{~m}^{2}(6 \mathrm{~m} \mathrm{X} \mathrm{4m).}$

Soil preparation for planting was carried out by two heavy harrows, a subsoil up to $0.45 \mathrm{~m}$ depth and a light harrowing. Then, on January 1, 2008, fertilization was applied at the plantation time with the addition of $25 \mathrm{~kg} \mathrm{ha}^{-1}$ of nitrogen $\mathrm{N}$ as urea, $150 \mathrm{~kg} \mathrm{ha}^{-1}$ of potassium oxide, $\mathrm{K}_{2} \mathrm{O}$, as potassium chloride $(\mathrm{KCl})$, and $75 \mathrm{~kg} \mathrm{ha}^{-1}$ of $\mathrm{P}_{2} \mathrm{O} 5$ in the form of simple superphosphate, calculated based on the results of soil chemical analysis carried out.

The planting of sugarcane was carried out on 08/01/2008. For the same, two stems of sugarcane of the cultivar RB 855453, with spacing between rows of $1.50 \mathrm{~m}$, where they were distributed in the furrow of planting and later cut off, enabling that the stems with three to four gems remain parallel, providing the distribution of 15 to 18 viable gems per meter of farrow.

Vinasse doses were applied on 10 December, 2010 as the plants had five to six fully expanded leaves. The chemical analysis of the vinasse was performed by the plasma ICP (ICAP 6000 Thermo) spectrometry method, using the necessary dilutions and resulted in the following concentration: $\mathrm{P}=67.36$ $\mathrm{mg} \mathrm{dm}^{-3} ; \mathrm{K}^{+}=387.67 \mathrm{mg} \mathrm{dm}^{-3} ; \mathrm{Mg}^{2+}=84.01 \mathrm{mg} \mathrm{dm}^{-3} ; \mathrm{Ca}^{2+}=122.7 \mathrm{mg} \mathrm{dm}^{-3} ; \mathrm{S}=95.1 \mathrm{mg} \mathrm{dm}^{-3} ; \mathrm{Zn}$ $=1.5 \mathrm{mg} \mathrm{dm}^{-3} ; \mathrm{Si}=8.23 \mathrm{mg} \mathrm{dm}^{-3} ; \mathrm{B}=0.035 \mathrm{mg} \mathrm{dm}^{-3} ; \mathrm{Fe}=3.31 \mathrm{mg} \mathrm{dm}^{-3} ; \mathrm{Cu}=0.32 \mathrm{mg} \mathrm{dm}^{-3} ; \mathrm{Mn}^{-3}$ $7.22 \mathrm{mg} \mathrm{dm}^{-3} ; \mathrm{Al}=0.097 \mathrm{mg} \mathrm{dm}^{-3} ; \mathrm{Co}=0.013 \mathrm{mg} \mathrm{dm}^{-3} ; \mathrm{Cr}=0.031 \mathrm{mg} \mathrm{dm}^{-3} ; \mathrm{Ba}=0.0136 \mathrm{mg} \mathrm{dm}^{-3} ; \mathrm{Cd}^{-3}$ $=0.0003 \mathrm{mg} \mathrm{dm}^{-3} ; \mathrm{Ni}=0.0274 \mathrm{mg} \mathrm{dm}^{-3} ; \mathrm{Sr}=0.867 \mathrm{mg} \mathrm{dm}^{-3}$; and $\mathrm{V}=0.0008 \mathrm{mg} \mathrm{dm}^{-3}$. In order to determine the $\mathrm{pH}$, electrical conductivity and salinity of the vinasse, a portable $\mathrm{pH}$ meter was used, obtaining values of $4.30 ; 2.39 \mathrm{mS} / \mathrm{cm}$ and 1.2 tpp respectively. 
For the determination of soil bulk density, macroporosity and total porosity, undisturbed soil samples were collected at 38, 75 and 111 days after application of the treatments (vinasse doses), through the volumetric rings method between the farrows of the sugarcane. After collection, samples were saturated in a polypropylene tray by gradually raising a water slide until they reached two third of the ring height, and then were taken to the tension table with a suction level corresponding to $60 \mathrm{~cm}$, height of water column for determination of microporosity and total porosity as described in (DONAGEMA et al., 2011). After determination of the microporosity, the samples were taken to the oven at $105^{\circ} \mathrm{C}$ for $48 \mathrm{~h}$ to determine the soil bulk density by the volumetric ring method.

For the determination of the stability of the aggregates were used two samples with preserved structure in the form of blocks in each plot and depth, then the aggregates retained in the sieve of 4.63 $\mathrm{mm}$ by dry sieving were used. From these materials were used three subsamples of $15 \mathrm{~g}$, two for each set of sieves, which was considered as repetition 1 and 2, submitted to vertical agitation in tank with water for $15 \mathrm{~min}$, with 30 oscillations per minute. The third subsample was used to determine soil moisture. The soil that was retained in each sieve was transferred to aluminum cans of known mass, which were then placed in an oven to dry at $105^{\circ} \mathrm{C}$ until constant weight, to determine the values of weighted average diameter (MWD) and geometric mean diameter (GMD) (LOSS et al., 2011)

The data were submitted to analysis of variance through the F test, the means of soil bulk density, macroporosity, total porosity, geometric mean diameter, weighted mean diameter, and soil organic matter were analyzed by the linear regression adjustment. The adjusted equations of the attributes, vinasse doses and collection time were evaluated by the F test.

\section{RESULTS AND DISCUSSION}

The analysis of variance of the means of interaction between dose, depth and time of soil bulk density, macroporosity, total porosity, geometric mean diameter, weighted average diameter, and organic matter were significant at $1 \%$ probability, except for interaction of the variable density, porosity total and organic matter (Table 2).

The values of soil bulk density showed a linear decrease with the doses at all depths, due to the high concentration of inorganic and organic ions present in the vinasse, which favored the flocculation of the clay, consequently the formation and stabilization of the aggregates increasing the porosity by 
decreasing soil bulk density. Soil bulk density at the four the depths at 38, 75 and 111 days after application of vinasse doses are described below (Figure 1).

Table 2. F values and coefficient of variation (CV) of soil bulk density (SD), macroporosity (Macro), total porosity (TP), geometric mean diameter (GMD), weighted mean diameter (MWD), and organic matter $(\mathrm{OM})$, after applying the doses of vinasse

\begin{tabular}{|c|c|c|c|c|c|c|}
\hline Souce of variation & SD & Macro & $\mathrm{TP}$ & GMD & MWD & $\mathrm{OM}$ \\
\hline Blocks & $6,39^{* *}$ & $0,39^{\text {ns }}$ & $2,63^{\mathrm{ns}}$ & $1,54^{\mathrm{ns}}$ & $0,87^{\mathrm{ns}}$ & $0,26^{\mathrm{ns}}$ \\
\hline Doses & $45,42^{* *}$ & $71,56^{* *}$ & $42,74^{* *}$ & $23,23^{* *}$ & $17,23^{* *}$ & $22.24^{* *}$ \\
\hline Prof. & $2,50^{\mathrm{ns}}$ & $18,29^{* *}$ & $1,69^{\mathrm{ns}}$ & $11,80^{* *}$ & $6,98^{* *}$ & $51,38^{* *}$ \\
\hline Time & $26,04^{* *}$ & $206,23^{* *}$ & $129,21^{* *}$ & $80,16^{* *}$ & $79,83^{* *}$ & $10,43^{* *}$ \\
\hline Doses x Deepth. & $0,73^{\mathrm{ns}}$ & $3,80^{* *}$ & $2,27^{* *}$ & $10,58^{* *}$ & $10,74^{* *}$ & $4,37^{* *}$ \\
\hline Doses x Time & $2,83^{* *}$ & $10,35^{* *}$ & $4,52^{* *}$ & $7,47^{* *}$ & $6,91^{\text {** }}$ & $0,98^{\mathrm{ns}}$ \\
\hline Prof. x Tempo & $3,08^{* *}$ & $14,39^{* *}$ & $6,83^{* *}$ & $15,45^{* *}$ & $17,01^{* *}$ & $2,69^{* *}$ \\
\hline Doses x Deepth. x Time. & $0,66^{\mathrm{ns}}$ & $3,25^{* *}$ & $0,65^{\mathrm{ns}}$ & $5,82^{* *}$ & $6,48^{* *}$ & $1,36^{\mathrm{ns}}$ \\
\hline $\mathrm{CV} 1(\%)$ & 3,64 & 13,79 & 3,90 & 11,02 & 6,97 & 12,13 \\
\hline CV $2(\%)$ & 2,32 & 8,94 & 2,68 & 11,58 & 6,04 & 9,10 \\
\hline CV $3(\%)$ & 3,23 & 10,20 & 3,23 & 10,50 & 5,65 & 6,76 \\
\hline
\end{tabular}


A

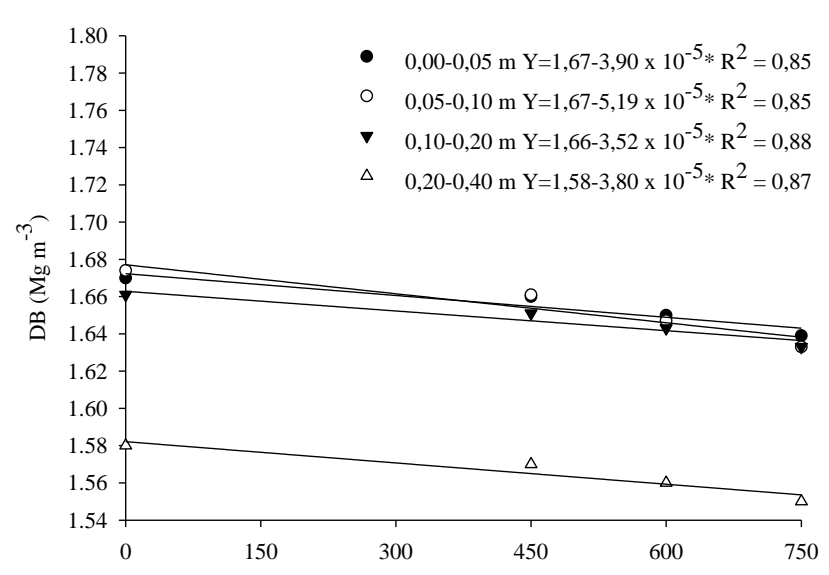

B

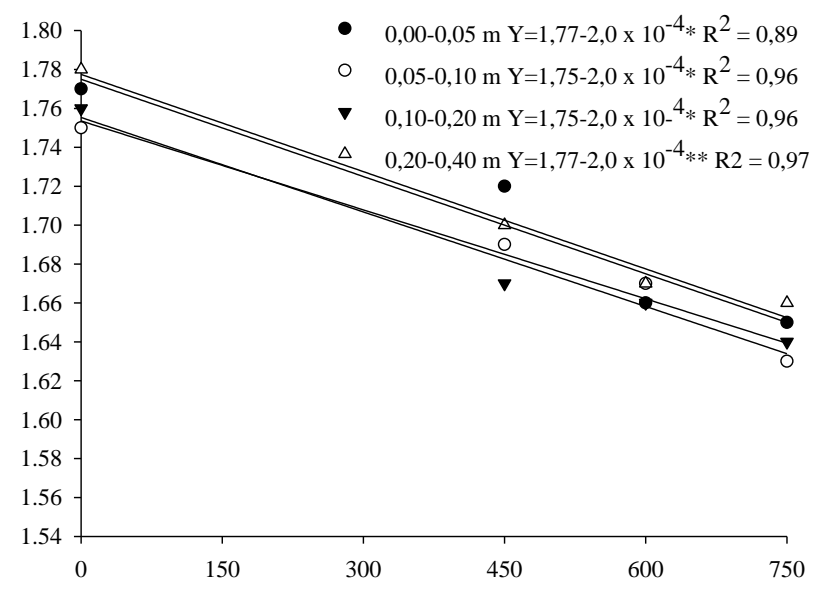

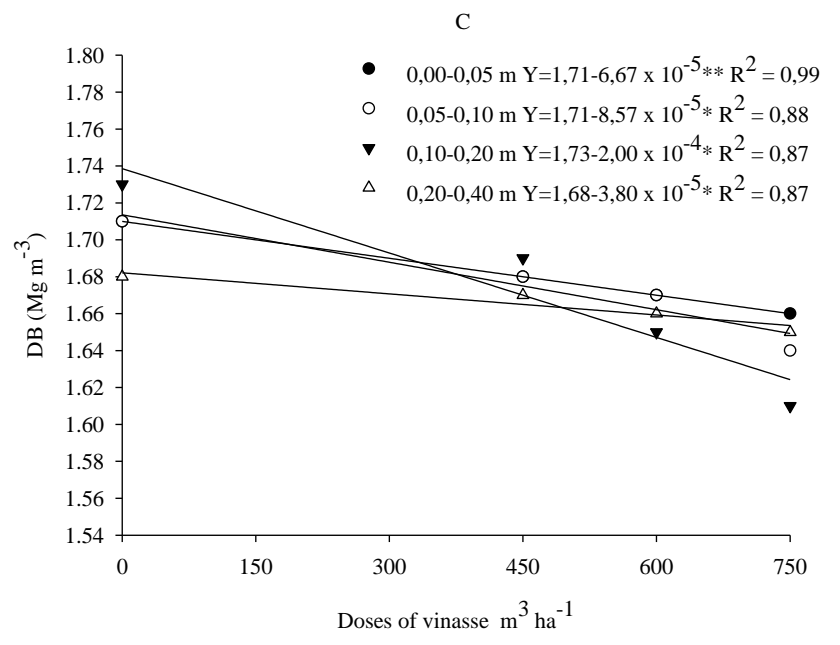

Figure 1. Soil bulk density at the four depths of a dystroferric red latosol under request of four doses of vinasse at three times, 38 (A), 75 (B) and 111 (C) days after application of the vinasse.

All linear equations adjusted for soil bulk density through vinasse doses were significant at the $5 \%$ level according to the t-test (Figure 1).

Vasconcelos et al. (2010) studied management systems and depths after application of vinasse in yellow latosol, and obtained average values of density around $1.60 \mathrm{Mg} \mathrm{m}^{-3}$, results similar to the ones found in Figure 1. According to Centurion et al. (2007), the increase of the organic matter of the soil promoted by the addition of vinasse favors the decrease of soil bulk density, due to the improvement in soil aggregation conditions.

The lowest densities were found when the $750 \mathrm{~m}^{3} \mathrm{ha}^{-1}$ dose of vinasse was used, which can be explained by the higher supply of electrolytes (any substance that, dissociated or ionized, causes positive ions and negative ions) and consequently higher concentration of cations such as $\mathrm{K}^{+}$and organic matter, 


\section{DOSES OF VINASSE AND ITS EFFECTS AT THE PHYSICAL ATTRIBUTES OF RHODIC HAPLUDOX UNDER SUGAR CANE}

that favors flocculation and consequently the formation of stable aggregates. For Costa et al. (2013), the organic compounds that constitute the organic matter participate in connections between the individual soil particles, also acting as cementing agents of the structural units, promoting aggregation and decreasing soil bulk density.

The macroaggregates are complex structures and represent a good indicator of soil physical quality, which reflects in the decrease of density values, increase in porosity, aeration and retention capacity and water infiltration in the soil (LOSS et al., 2015).

Soil macroporosity at four depths at 38, 75 and 111 days after application of vinasse doses are described below (Figure 2).

A

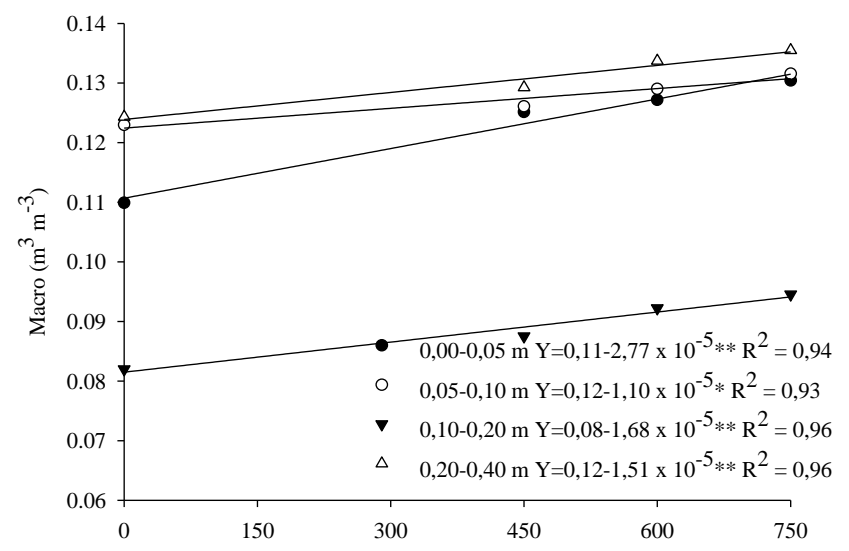

B

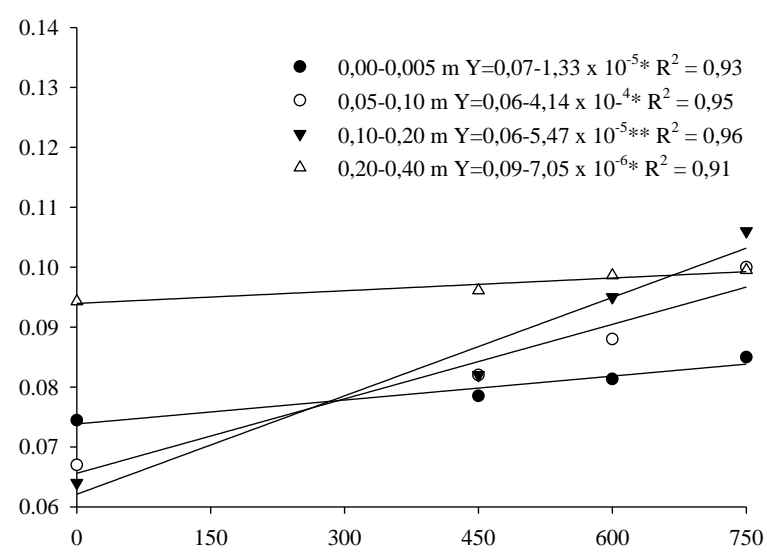

$\mathrm{C}$

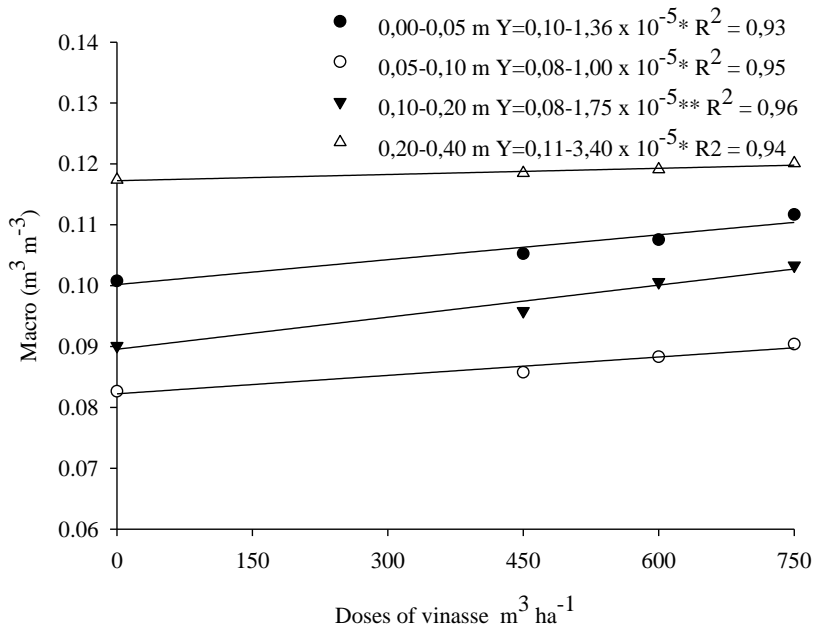

Figure 2. Macroporosity at the four depths of a dystroferric red latosol under request of four doses of vinasse at three times, 38 (A), 75 (B) and 111 (C) days after application of the vinasse. 
The Figure 2 shows that all linear equations adjusted for macroporosity and vinasse doses were significant at the $5 \%$ level according to the t-test (Figure 2).

In this context, in relation to macroporosity, can be observed an increase in the order of $15.4 \%$ of the dose of 0 up to $750 \mathrm{~m}^{3} \mathrm{ha}^{-1}$ of vinasse (Figure 2). The dose of $750 \mathrm{~m}^{3} \mathrm{ha}^{-1}$ gave the soil a large amount of organic matter which improved its structure, promoting an increase in the volume of macropores at all depths evaluated up to 111 days after application of vinasse.

The most usual classification of porosity refers to its size distribution being divided into micro and macropores. In relation to the pores, the infiltration of water into the soil consists of the entrance of water through the surface into the soil and can be influenced by the physical properties of the soil. Also in the sense of physical quality the aeration of the soils refers to the ability of a soil to meet the respiratory demand of the soil. The increase of the macroporosity provided by the vinasse application was beneficial to the soil, as it improved its physical quality which may have had as direct consequence favoring the development of the plants, mainly of the sugar cane that has a root system that reaches to greater depths when compared to annual crops.

It is worth mentioning that the growth of the root system of plants occurs mainly through the macropores, being this attribute a good indicator of the physical quality of the soil (BERGAMIN et al., 2010). In addition, it promotes a better oxygenation of the soil and allows the plant through its welldeveloped root system, to explore a huge volume of soil, by absorbing more nutrients and water, as well as giving the plant greater resistance to drought and other phenomena climatic conditions. The management system with vinasse provided the highest macroaggregation values to the soil, reflecting positively on macroporosity (COSTA et al., 2013) and (Silva et al., 2006a). According to Meurer (2010), the presence of macropores in the soil provides better conditions for water infiltration and better gas exchange between the soil and the atmosphere.

The loss of soil physical quality is related to the degradation of its structure, and can be evaluated by total soil porosity, which considers the pore space, water and air flow (ABRÃO et al., 2015). Soil total porosity at the four depths at 38, 75 and 111 days after application of vinasse doses are described below (Figure 3). 


\section{DOSES OF VINASSE AND ITS EFFECTS AT THE PHYSICAL ATTRIBUTES OF RHODIC HAPLUDOX UNDER SUGAR CANE}

A

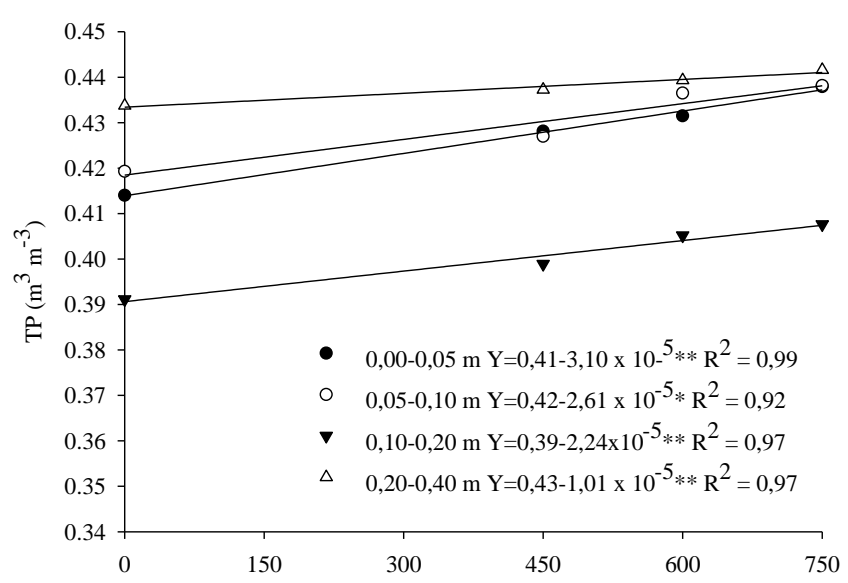

B

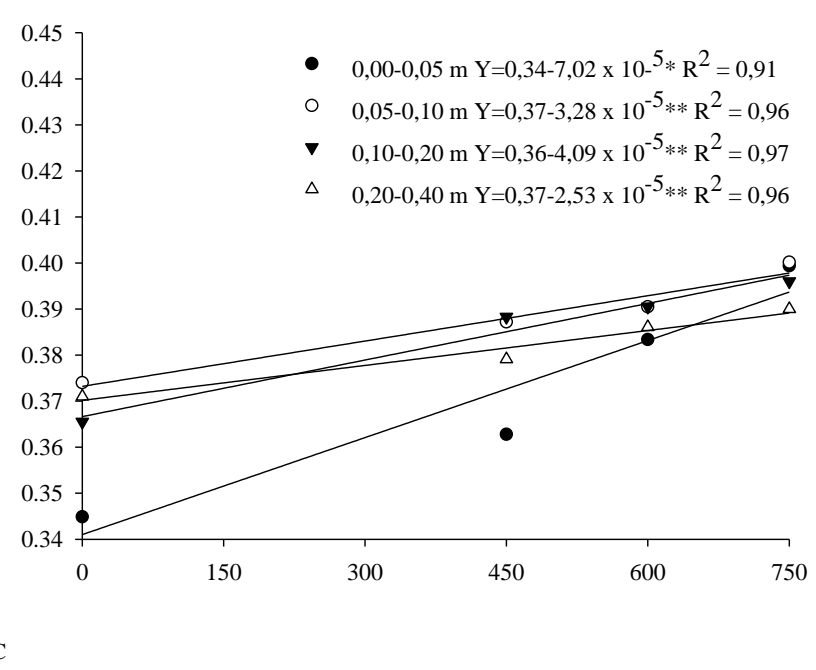

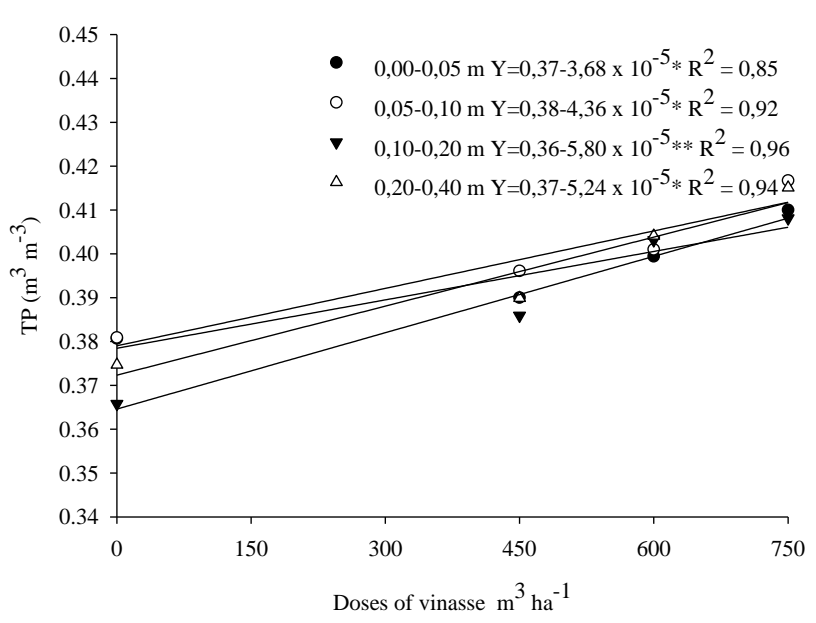

Figure 3. Total porosity at the four depths of the dystroferric red latosol under application of four doses of vinasse at three harvest times, 38 (a), 75 (b) and 111 (c) days after vinasse application.

All linear equations adjusted for total porosity and vinasse doses were significant at the $5 \%$ level according to the t-test (Figure 3).

Thus, there is great importance regarding total porosity, it can be observed a linear increase of its values with the increase in vinasse doses at all studied depths at 38, 75 and 111 days after application of the vinasse (Figure 3) agreeing the values found for soil macroporosity.

The total porosity increased by $6.8 \%$ with mean doses of vinasse, Dantas et al. (2010) found results in dystroferric red latosol in which the values of total porosity are statistically higher when there was an increase of organic matter in relation to the control. An ideal soil for agricultural production should present $0.50 \mathrm{~m}^{3} \mathrm{~m}^{-3}$ of total porosity, being $1 / 3$ of macro and 2/3 of micropores. Also according to the author, most plants develop satisfactorily, root system when the volume of macropores is above 
$0.10 \mathrm{~m}^{3} \mathrm{~m}^{-3}$. Therefore, the soil presents conditions of compaction that can directly influence root development and consequently affect productivity.

Some physical attributes of the soil can be analyzed through indexes, thus, the aggregation and stability of soil aggregates can be determined by means of the weighted average diameter, geometric mean diameter (TORRES et al., 2015). Geometric mean diameter of soil aggregates at four depths at 38, 75 and 111 days after application of vinasse doses are described below (Figure 4).

A

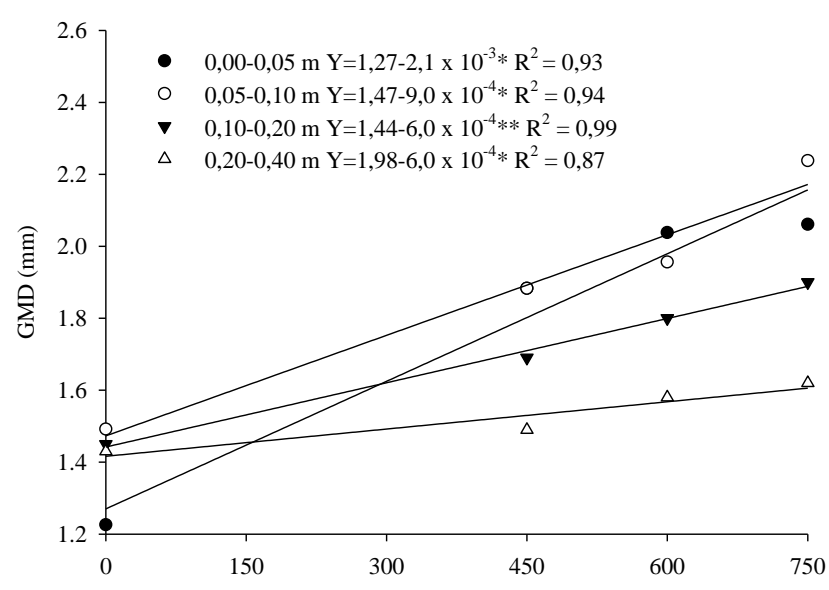

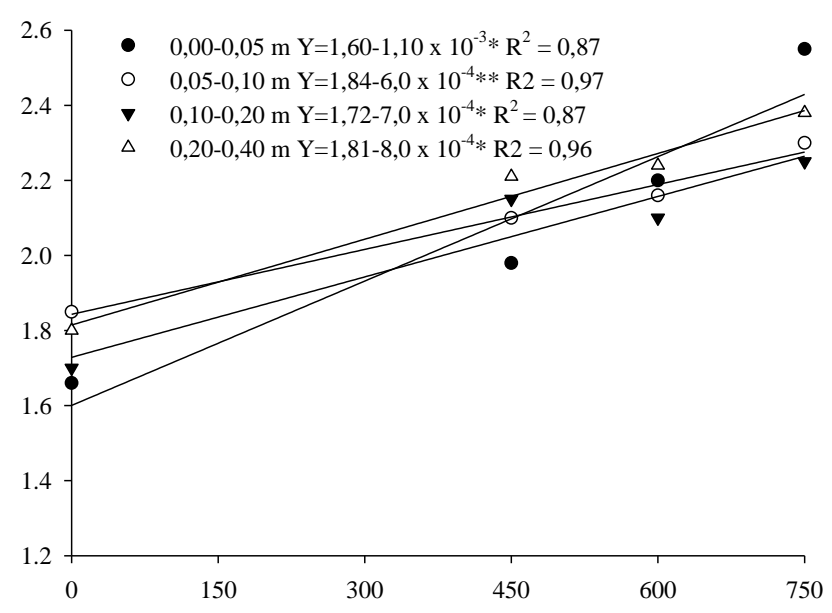

$\mathrm{C}$

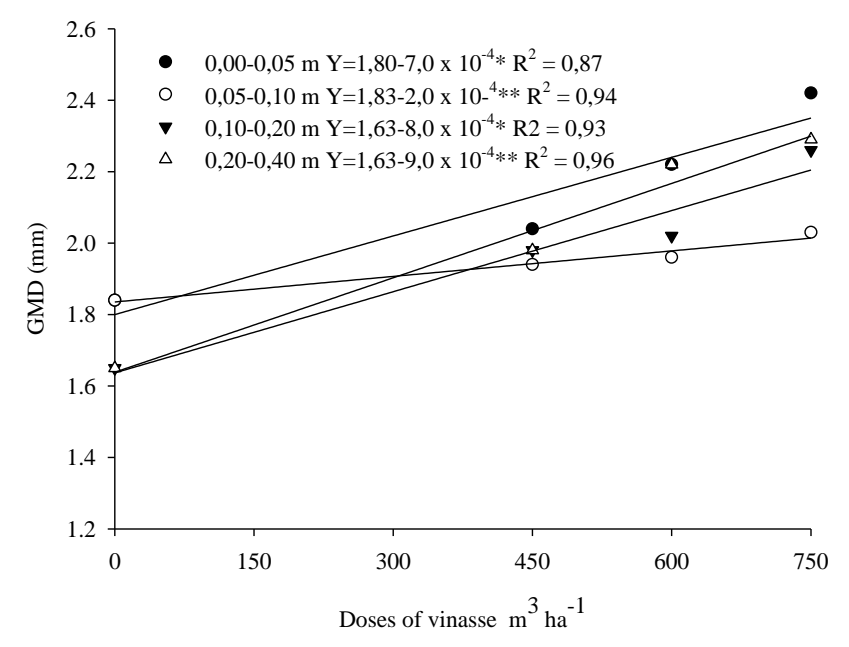

Figure 4. Geometric mean diameter (GMD) at four depths of a dystroferric red latosol under application of four doses of vinasse at three harvest times, 38 (a), 75 (b) and 111 (c) days after application of the vinasse.

Figure 4 shows that all linear equations adjusted for GMD and vinasse doses were significant at the $5 \%$ level according to the t-test (Figure 4). 
When looking at the data of Figure 4, a mean increase of $33 \%$ in the geometric mean diameter (GMD) was observed with increasing vinasse rates in the first three depths, which shows that the aggregates of this depth are more susceptible to the treatments applied. In the depths of $0.20-0.40 \mathrm{~m}$, GMD increased by $28 \%$. The increase in the geometric mean diameter is directly related to the organic matter, according to Meurer (2010), the greater stability that the organic matter promotes to the aggregates also makes it difficult to spread and drag the particles through the rainwater, increasing soil resistance to erosion. Vasconcelos et al. (2010) also reported higher resistance to disintegration by wet sieving of aggregates of a dystroferric red latosol cultivated with sugarcane, after addition of organic residues.

It is common to use indicators and indices, analyzed separately or together to evaluate the physical quality of the soil. Indicators such as the weighted mean diameter may indicate changes in soil management systems (TORRES, et al., 2015). Thus, the stability of the aggregates can be used as an index of agricultural sustainability, since it is influenced by chemical, physical and biological attributes of the soil. Weighted mean diameter of soil aggregates at four deTPhs at 38, 75 and 111 days after application of vinasse doses are described below (Figure 5).

The linear equations adjusted for DMP and vinasse doses were significant at the $5 \%$ level according to the t-test, except for the depth of 0.10-0.20 m at 75 days after application and at depth 0.00-0.05 $\mathrm{M}$ at 111 days after application of the vinasse (Figure 5).

In relation to the stability of the aggregates, the MWD was also calculated, with average gains of $16.1 \%$ at 38,75 and 111 days after application of the vinasse at doses of 0 up to $750 \mathrm{~m}^{3} \mathrm{ha}^{-1}$ at all depths (Figure 5). Silva et al. (2006b) also demonstrated the importance of organic compounds in the stabilization of soil aggregates by MWD. 


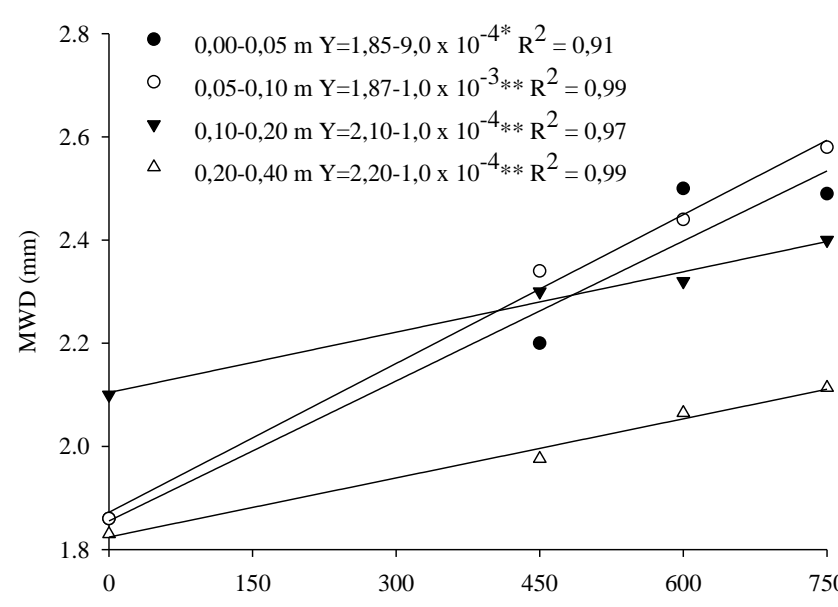

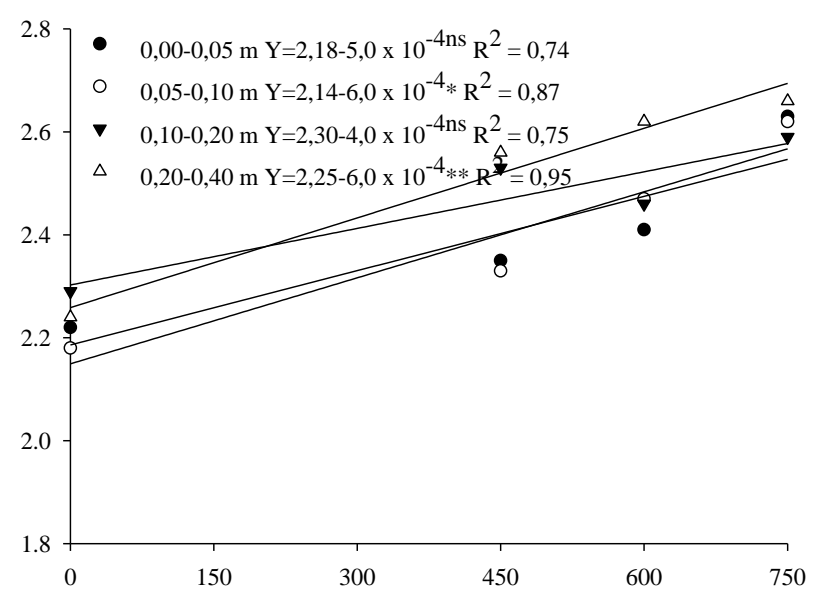

C

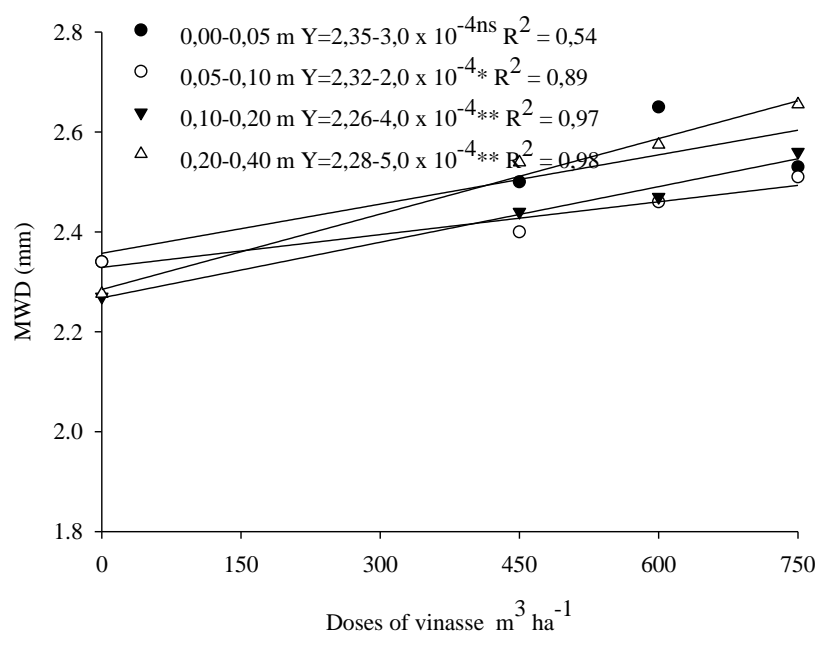

Figure 5. Weighted average diameter (MWD) at four depths of a dystroferric red latosol under application of four doses of vinasse at three times, 38 (a), 75 (b) and 111 (c) days after application of the vinasse.

Heid et al. (2009), when comparing cultivation systems in dystroferric red latosol, verified an increase in GMD and DMP caused by the higher content of organic matter. Soil organic matter at four depths at 38, 75 and 111 days after application of vinasse doses are described below (Figure 6). 

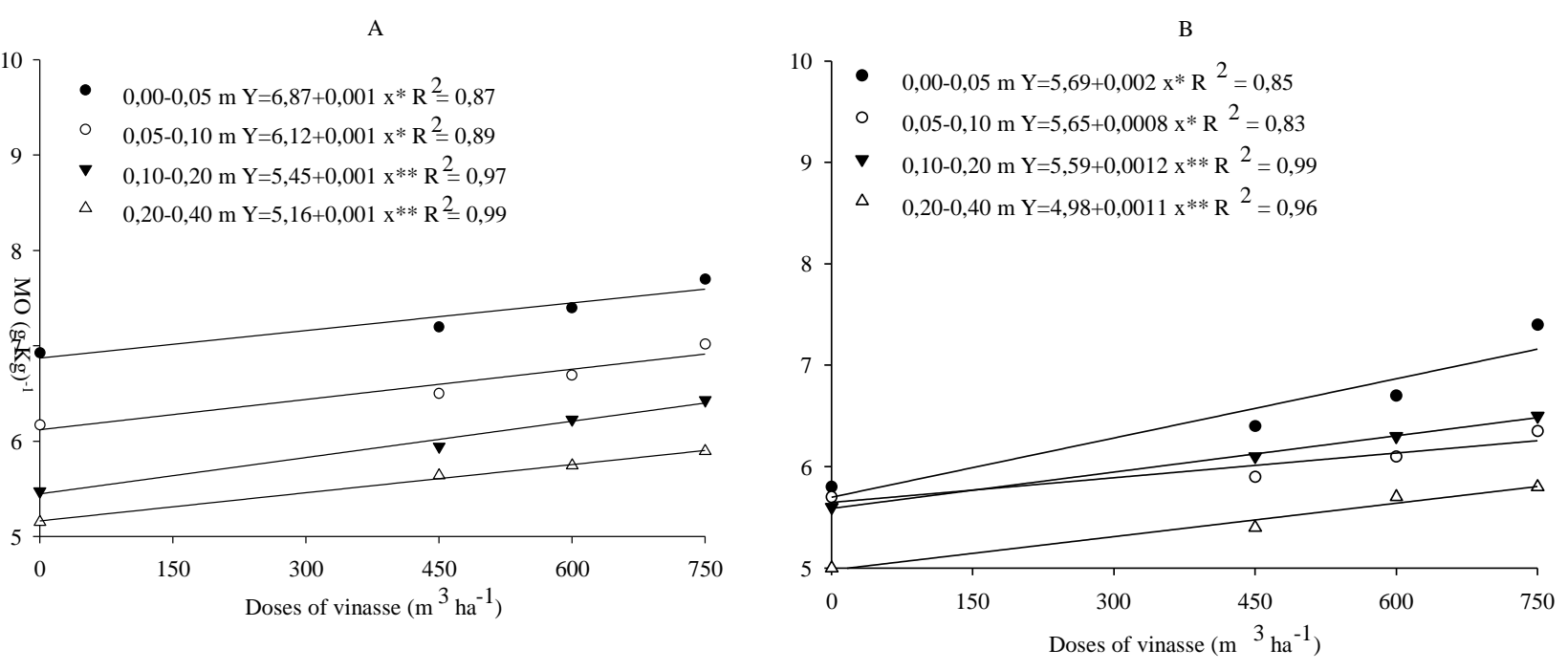

$\mathrm{C}$

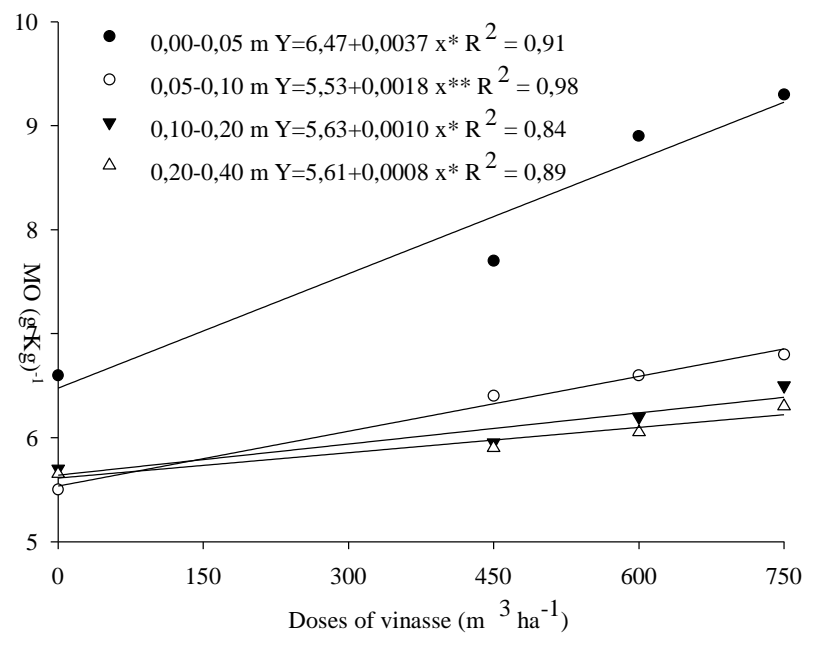

Figure 6. Organic matter content $(\mathrm{OM})$ at four depths of a dystroferric red latosol under application of four doses of vinasse at three harvest times, 38 (a), 75 (b) and 111 (c) days after application of the vinasse.

All linear equations adjusted for organic matter and vinasse doses were significant at the 5\% level according to the t-test (Figure 6).

Regarding to the organic matter, it was observed an increase in the soil content from the lowest to the highest dose of vinasse (Figure 6).

Prado et al. (2014), when studying the application of doses of vinasse in dystroferric red latosol, observed higher values of stability of aggregates in the area that received the highest amount of vinasse and consequently also received higher content of organic matter. Thus, it is evident that sugarcane management systems that received higher amounts of vinasse and consequently higher doses of organic 
residues presented higher stability of aggregates in water, which according to Jiang et al. (2012) and Vasconcelos et al. (2010).

The increase of the organic matter concentration promoted by the addition of vinasse doses is beneficial both for the improvement of soil fertility by increasing the cation exchange capacity, as well as for having a cementing action in the aggregates, acting in the protection of the same. This protection conferred by organic matter is responsible for increasing the stability of aggregates in water.

\section{CONCLUSIONS}

The application of vinasse decreases soil bulk density, increases macroporosity, total porosity, geometric mean diameter, and weighted average diameter of soil cultivated with sugarcane.

The increase of the organic matter concentration promoted by the addition of vinasse doses promotes improvements in the physical and chemical qualities of the soil.

\section{REFERENCES}

ABRÃO, S. F.; SECCO, D.; REINERT, D. J.; REICHERT, J. M.; EBLING, A. A. 2015. Impacto do florestamento com Pinus taeda L. na porosidade e permeabilidade de um Cambissolo húmico. Revista Árvore, Viçosa, v.39, n.6, p.1073-1082.

BAYER, C.; MIELNICZUK, J. Dinâmica e função da matéria orgânica. 2008. In: SANTOS, G. A., SILVA, L. S., CANEllaS, L. P., CAMARGO, F. A. O. (ORG.). Fundamentos da matéria orgânica do solo: ecossistemas tropicais e subtropicais. Porto Alegre-RS: Metrópole, v. 1, p. 101120.

BERGAMIN, A. C.; VITORINO, A. C. T.; FRANCHINI, J. C.; SOUZA, C. M. A.; SOUZA, F. R. 2010. Compactação em um Latossolo Vermelho distroférrico e suas relações com o crescimento radicular do milho. Revista Brasileira de Ciência do Solo, Viçosa, v.34, n.3, p.681-691.

CENTURION, J. F.; FREDDI, O. S.; ARATANI, R. G.; METZNER, A. F. M.; BEUTLER, A. N.; ANDRIOLI, I. 2007. Influência do cultivo da cana-de-açúcar e da mineralogia da fração argila nas propriedades físicas de Latossolos Vermelhos. Revista Brasileira de Ciência do Solo, Viçosa, v.31, n.2, p.199-209.

COSTA, C. S.; PEDROSA, E. M. R.; ROLIM, M. M.; SANTOS, H. R. B.; CORDEIRO NETO, A. T. 2013. Effects of vinasse application under the physical atributes of soil covered with sugarcane straw. Engenaharia Agrícola, Jaboticabal, v.33, n.4, p.636 - 646.

DANTAS, V. B.; MORAIS, F. A.; PEREIRA, J. O.; CAlleGARI, R. A.; GÓES, G. B. 2010. Comportamento físico de um Latossolo Vermelho distroférrico sob diferentes doses de palhada de aveia. Revista verde de agroecologia e desenvolvimento sustentável, Pombal, v.5, n.5, p.06-11.

DONAGEMA G. K.; CAMPOS D. V. B.; CALDERANO S. B.; TEIXEIRA W. G.; VIANA J. H. M. 2011. Manual de métodos de análise de solos. Rio de Janeiro: Embrapa Solos, 88p.

GARCIA, R. A.; ROSOLEM, C. A. 2010. Agregados em um Latossolo sob sistema plantio direto e rotação de culturas. Pesquisa Agropecuária Brasileira, Brasilia, v.45, n.12, p.1489-1498. 


\section{DOSES OF VINASSE AND ITS EFFECTS AT THE PHYSICAL ATTRIBUTES OF RHODIC HAPLUDOX UNDER SUGAR CANE}

HEID, D. U.; VITORINO, A. C. T.; TIRLONI, C.; HOFFMANN, N. T. K. 2009. Frações orgânicas e estabilidade dos agregados de um Latossolo Vermelho distroférrico sob diferentes usos. Revista Ciências Agrárias, Belém, v.51, n.1, p.143-160.

JIANG, Z. P.; LI, Y. R.; WEI, G. P.; LIAO, Q.; SU, T. M.; MENG, Y. C.; ZHANG, H. Y.; LU, C. Y. 2012. Effect of long-term vinasse aplication on physico-chemical properties of sucarcane field soils. Sugar Tech, Bombaim, v.14, n.4, p.412 - 417.

LOSS, A.; BASSO, A.; OLIVEIRA, B. S.; KOUCHER, L. P.; OLIVEIRA, R. A.; KURTZ, C.; LOVATO, P. E.; CURMI, P.; BRUNETTO, G.; COMIN, J. J. 2015. Carbono orgânico total e agregação do solo em sistema de plantio direto agroecológico e convencional de cebola. Revista Brasileira de Ciência do Solo, Viçosa, v.39, n.1, p.1212-1224.

LOSS, A.; PEREIRA, M. G.; GIÁCOMO, S. G.; PERIN, A.; ANJOS, L. H. C. 2011. Agregação, carbono e nitrogênio em agregados do solo sob plantio direto com integração lavoura-pecuaria. Pesquisa Agropecuária Brasileira, Brasília, v.46, n.10, p.1269 - 1276.

MATOS, A, T.; GARIGLIO, H. A. A.; MONACO, P. A, V. 2013. Deslocamento miscível de cátions da vinhaça em colunas de solo. Revista Brasileira de Engenharia Agrícola e Ambiental, Campina Grande, v.17, n.7, p.743 - 749 .

MEURER, E. J. 2010. Fundamentos de Química do Solo. Porto Alegre: Evangraf Ltda, 2010. 100p.

OliveIRA, B. G.; CARVAlHO, J. L. N.; CERRI, C. E. P.; CERRI, C. C.; FEIGL, B. J. 2013. Soil greenhouse gas fluxes from vinasse application in Brazilian sugarcane áreas. Geoderma, Amsterdam, v.200, p. $77-84$.

PEREIRA, A. H. F.; VITORINO, A. C. T.; PRADO, E. A. F.; BERGAMIN, A. C.; MAUAD, M.; ARANTES, H. P. 2015. Least limiting water range and load bearing capacity of soil under types of tractor-trailers for mechanical harvesting of green sugarcane. Revista Brasileira de ciência do solo, Viçosa, v.39, n.6, p.1603-1610.

PRADO, E. A. F.; VITORINO, A. C. T.; OLIVEIRA, W. H.; ESPINDOLA, D. L. P.; ARANTES, H. P. 2014. Índice de dispersão de agregados de um Latossolo Vermelho distroférrico cultivado com cana sob aplicação de vinhaça. Semina: Ciências Agrárias, Londrina, v.35, n.4, p.2347-2356.

RIBEIRO, B. T.; LIMA, J. M.; CURI, N.; OLIVEIRA, G. C. 2013. Aggregate breakdown and dispersion of soil samples amended with sugarcane vinasse. Scientia Agricola, Piracicaba, v. 70, n.6, p.435 441.

SANTOS, H.G., P.K.T. JACOMINE, L.H.C. ANJOS, V.A. OLIVEIRA, J.F. LUBRERAS, M.R. COELHO, J.A. ALMEIDA, T.J.F. CUNHA, AND J.B. OLIVEIRA. 2013. Sistema brasileiro de classificação de solos. 2nd ed. Embrapa Informação Tecnológica, Brasília, BR.

SILVA, C. S. 2009. Manual de análises químicas de solos, plantas e fertilizantes. Brasília: Embrapa Informação e Tecnologia, 300p.

SILVA, A. J. N.; CABEDA, M. S. V.; CARVALHO, F. G. 2006a. Matéria orgânica e propriedades físicas de um Argissolo Amarelo coeso sob sistemas de manejo com cana-de-açúcar. Revista Brasileira de Engenharia Agrícola e Ambiental, Campina Grande, v.10, n.3, p.579-585.

SILVA, A. J. N.; CABEDA, M. S. V.; CARVALHO, F. G.; LIMA, J. F. W. F. 2006b. Alterações físicas de um Argissolo Amarelo sob diferentes sistemas de uso e manejo. Revista Brasileira de Engenharia Agrícola e Ambiental, Campina Grande, v.10, n.3, p.76-83.

SOIL SURVEY STAFF. 2014. Keys to soil taxonomy. 12th ed. Washington, DC: USDA-Natural Resources Conservation Service, USA.

TORRES, J. L. R.; PEREIRA, M. G.; ASSIS, R. L.; SOUZA, Z. M. 2015. Atributos físicos de um Latossolo Vermelho cultivado com plantas de cobertura, em semeadura direta. Revista Brasileira de Ciência do Solo, Viçosa, v.39, n.1, p.428-437. 
VASCONCELOS, R. F. B.; CANTALICE, J. R. B.; OLIVEIRA, V. S.; COSTA, Y. D. J.; CAVALCANTE, D. M. 2010. Estabilidade de agregados de um Latossolo Amarelo distrocoeso de tabuleiro costeiro sob diferentes aportes de resíduos orgânicos da cana-de-açúcar. Revista Brasileira de Ciência do Solo, Viçosa, v.34, n.1, p.309-316.

Received in: May 13, 2016

Accepted in: July 11, 2017 